\title{
PENGOLAHAN LIMBAH PLASTIK MENJADI PRODUK KREATIF SEBAGAI PENINGKATAN EKONOMI MASYARAKAT PESISIR
}

\author{
Zulfan Arico ${ }^{1)}$; Sri Jayanthi ${ }^{2}$ \\ ${ }^{1)}$ Fakultas Teknik Universitas Samudra, \\ ${ }^{2)}$ Fakultas Keguruan dan Ilmu Pendidikan Universitas Samudra, \\ arico_zulfan@yahoo.co.id
}

\begin{abstract}
Increasing garbage in Langsa City especially in Gampong Kuala Langsa will become a serious problem if not solved. On the one hand, the invention of this plastic has a tremendous positive effect, because plastic has advantages over other materials. Based on these analyzes, the community service activities need to be done with the aim of improving the economy of Langsa City, especially coastal communities. Based on the results of further evaluation also recorded, some of the practical benefits gained by mothers in the village of Kuala Langsa, that is they get clear and whole information about the essence of community empowerment in terms of knowledge and skills. Meaningful for created of new jobs that are innovative from development of home industry, mothers who participated in the training obtained a clear picture of the business climate development step by using waste of coffee wrap, trainees also get a clear and whole picture about the benefits of waste if managed properly. The next stage plan is Assistance to the processing of plastic waste into a product so as to obtain quality standard both quality and quantity of quality and product quality and evaluation program to see how far the program is beneficial for mothers in the village of Kuala Langsa.
\end{abstract}

Keywords: Creative Product, Kuala Langsa, Plastic Waste.

\begin{abstract}
Abstrak
Semakin meningkatnya sampah di Kota Langsa khususnya di Gampong Kuala Langsa ini akan menjadi masalah serius bila tidak dicari penyelesaiannya. Di satu sisi penemuan plastik ini mempunyai dampak positif yang luar biasa, karena plastik memiliki keunggulankeunggulan dibanding material lain. Berdasarkan analisis tersebut maka kegiatan pengabdian masyarakat ini perlu dilakukan dengan tujuan dapat meningkatkan perekonomian masyarakat Kota Langsa khususnya masyarakat pesisir. Berdasarkan hasil evaluasi tindak lanjut juga terekam, beberapa manfaat praktis yang diperoleh oleh Ibu-ibu di Desa Kuala Langsa, yaitu mereka mendapatkan informasi yang jelas dan utuh mengenai hakekat pemberdayaan masyarakat dari segi pengetahuan dan keterampilan. Bermakna untuk menciptakan lapangan pekerjaan baru yang sifatnya inovatif dari pengembangan industri rumah tanggga, ibu-ibu yang menjadi peserta pelatihan memperoleh gambaran yang jelas mengenai langkah pengembangan iklim usaha dengan memanfaatkan limbah bungkus kopi, peserta pelatihan juga mendapatkan gambaran yang jelas dan utuh tentang manfaat limbah jika dikelola dengan baik. Rencana tahapan berikutnya adalah Pendampingan pengolahan limbah plastik menjadi produk sehingga didapatkan standar mutu baik kualitas maupun kuantitas yang standar dan bermutu dari produk serta evaluasi program untuk melihat seberapa jauh program ini bermanfaat bagi Ibu-ibu di desa Kuala Langsa.
\end{abstract}

Kata Kunci: Limbah Plastik, Kuala Langsa, Produk Kreatif, 


\section{PENDAHULUAN}

Di Indonesia, kebutuhan plastik terus meningkat hingga mengalami kenaikan rata-rata 200 ton per tahun. Tahun 2002, tercatat 1,9 juta ton, di tahun 2003 naik menjadi 2,1 juta ton, selanjutnya tahun 2004 naik lagi menjadi 2,3 juta ton per tahun. Di tahun 2010 menjadi 2,4 juta ton, dan pada tahun 2011, sudah meningkat menjadi 2,6 juta ton. Akibat dari peningkatan penggunaan plastik ini adalah bertambah pula sampah plastik (Surono, 2011). Berdasarkan data Kementerian Lingkungan Hidup (KLH), setiap hari penduduk Indonesia menghasilkan $0,8 \mathrm{~kg}$ sampah per orang atau secara total sebanyak 189 ribu ton sampah/hari. Dari jumlah tersebut $15 \%$ berupa sampah plastik atau sejumlah 28,4 ribu ton sampah plastik/hari.

Berdasarkan penelitian

Dharmawansyah (2015) Jumlah timbunan sampah Kota Langsa dalam kurun waktu lima tahun mulai dari tahun 2008 sampai dengan tahun 2012 mengalami peningkatan sebesar $10 \%$ pertahun. Timbunan sampah pada tahun 2012 lebih dari $324 \mathrm{~m}^{3}$ per hari, sementara daya angkut sampah hanya mencapai 22 persen dari total keseluruhan sampah tersebut. Kondisi ini dikhawatirkan akan menyebabkan terjadinya penurunan kualitas lingkungan, terlihat dari adanya tumpukan-tumpukan sampah yang tidak terangkut di pinggir-pinggir jalan ditengah kota. Berdasarkan keterangan Geuchik Gampong Kuala Langsa juga mengatakan bahwa tidak adanya mobil pengangkut sampah yang beroperasi di sekitar wilayah Gampong Kuala Langsa tersebut untuk membersihkan atau mengangkut sampahsampah rumah tangga sehingga masyarakat membuang sampah-sampah tersebut di kolong rumah atau laut

Semakin meningkatnya sampah di Kota Langsa khususnya di Gampong Kuala Langsa ini akan menjadi masalah serius bila tidak dicari penyelesaiannya. Penanganan sampah plastik yang populer selama ini adalah dengan 3R (Reuse, Reduce, Recycle). Reuse adalah memakai berulang kali barang-barang yang terbuat dari plastik. Reduce adalah mengurangi pembelian atau penggunaan barang-barang dari plastik, terutama barang-barang yang sekali pakai. Recycle adalah mendaur ulang barang-barang yang terbuat dari plastik. Di satu sisi penemuan plastik ini mempunyai dampak positif yang luar biasa, karena plastik memiliki keunggulankeunggulan dibanding material lain. Menurut Putra (2010) keunggulan plastik dibanding material lain diantaranya kuat, ringan, fleksibel, tahan karat, tidak mudah pecah, mudah diberi warna, mudah dibentuk, serta isolator panas dan listrik yang baik. Oleh sebab itu, limbah plastik memiliki banyak keunggulan jika dapat dimanfaatkan menjadi produk daur ulang.

Bisnis daur ulang sampah telah berlangsung sejak lama dan merupakan bisnis besar yang dijalankan secara sistematis. Untuk menjadi pebisnis daur ulang plastik, seorang perlu membangun sistem pengumpulan sampah yang baik, menjalin kerjasama dengan pemulung, memiliki fasilitas pengolahan sampah, serta mengenal pangsa pasar produk daur ulang plastik yang diproduksinya. Meskipun tetap menggunakan plastik sebagai bahan baku utama, bisnis kreasi sampah plastik yang penulis tawarkan tidak sekompleks bisnis daur ulang plastik yang bercorak industrial dan bisnis ini dapat dilakukan secara mandiri.

Sebagai produk kreatif, karya kreasi sampah plastik memiliki nilai komersial yang menjanjikan. Produk ini memiliki daya jual yang dapat menghasilkan keuntungan bisnis kreasi sampah plastik dapat menjadi salah satu gerakan pemberdayaan komunitas di wilayah pesisir Kota Langsa. Hal ini merupakan salah satu kekuatan produk yang dapat dikomunikasikan pada konsumen. Proses produksi yang dilakukan melibatkan banyak pihak, mulai dari pemulung, penjahit, tenaga administratif, dan lainlain. Menjalankan bisnis sampah plastik 
berarti menambah lapangan pekerjaan dan membuka kemungkinan peningkatan kesejahteraan masyarakat Kota Langsa. Hal ini tentunya akan mendorong penurunan angka kemiskinan di Kota Langsa.

Angka kemiskinan Kota Langsa jika ditinjau dari Hasil Pengolahan Sementara PPLS (Pendataan Program Perlindungan Sosial) Tahun 2011 Rumah Tangga Menengah Kebawah akan diperoleh prosentase terbesar rumah tangga menengah kebawah di Kecamatan Langsa Barat sebesar 24,31\% yang merupakan wilayah pesisir Kota Langsa. Berdasarkan data Badan Pusat Statistik (BPS) Kota Langsa tahun 2015 garis kemiskinan Kota Langsa berada pada angka 298,749 (Rp/Kap/Bln) dengan ketentuan menurut Kepala Badan Pusat Statistik Rusman Heriawan mengatakan bahwa kategori miskin adalah mereka dengan tingkat pengeluaran per kapita per bulan sebesar Rp211.726 atau sekitar Rp7000 per hari (BPS, 2015). Berdasarkan analisis tersebut maka kegiatan pengabdian masyarakat ini perlu dilakukan dengan tujuan dapat meningkatkan perekonomian masyarakat Kota Langsa khususnya masyarakat pesisir.

\section{METODE PELAKSANAAN}

Sebagai solusi atas permasalahan yang sedang dihadapi oleh kelompok mitra sepertiyang telah diuraikan diatas, maka dapat diterapkan beberapa metode kegiatan yaitu:

(1) Survey Potensi Desa

Survey dilakukan untuk mengetahui daerah mana pada Gampong Kuala Langsa yang mempunyai potensi untuk dilaksanakannya kegiatan ini.

(2) Mengadakan dialog melalui kegiatan program FGD (Focuss Group Disscussion.).

FGD dilaksanakan oleh tim pelaksana kegiatan denga mitra serta pihakpihaklainnya yang terkait, antara lain pihak pemerintahan desa. Tujuan kegiatan FGD adalah untuk mengkoordinasikan pelaksanaan kegiatan, penggalian potensi keterlibatan mitra serta pihak pendukung lainnya untuk mengatasi permasalahan yang ada, serta evaluasi setiap tahapan pelaksanaan kegiatan.

(3) Pemberian pelatihan desain yang inovatif.

Pelatihan desain yang inovatif ini adalah bagian sebagian kegiatan yang membuat produk di dalam mendesainnya. Kegiatan desain ini mengambil limbah plastik disekitarnya untuk dijadikan souvenir.

(4) Pelatihan pembuatan produk yang baik.

Pada pelatihan ini menyamakan persepsi bagi para pengrajin sehingga hasil yang dihasilkan oleh para pengrajin sama.

(5) Peningkatan teknologi pembuatan produk.

Peningkatan produksi dilakukan karena adanya beberapa alat seperti mesin jahit. Penambahan sebagian alat -alat dimaksudkan untuk bisa mengejar target penjualan yang lebih banyak.

\section{HASIL DAN PEMBAHASAN}

Pelaksanaan kegiatan Pengabdian kepada Masyarakat "Pengolahan Limbah Plastik Menjadi Produk Kretaif Sebagai Peningkatan Ekonomi Masyarakat Psesisir" yang menyasar Ibu PKK perwakilan masing-masing dusun di desa Kuala Langsa sampai pada bulan September 2016 yang telah dilaksanakan $60 \%$ program yaitu: sosialisasi dan pelatihan pengolahan bungkus kopi menjadi produk kreatif. Hal yang masih berlangsung sampai saat ini adalah pendampingan kelompok dalam hal memperbaiki kualitas dan penongkatan kemahiran ibu-ibu dalam meningkatkan hasil produksi. 


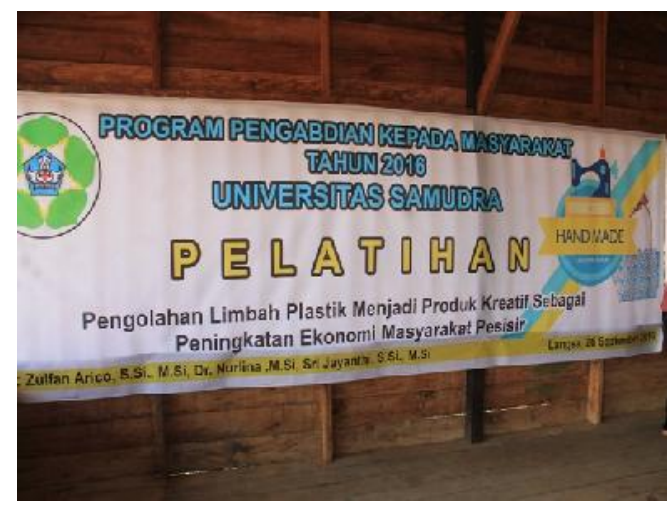

Gambar 1: Spanduk Kegiatan

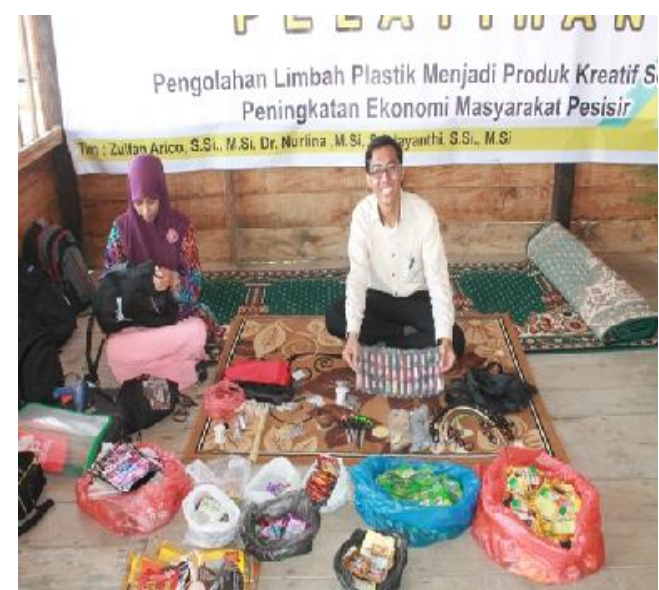

Gambar 2: Alat dan Bahan

\section{Tahapan Pelaksanaan Kegiatan}

Sesuai dengan permasalahan yang dihadapi oleh warga masyarakat desa Kuala Langsa dalam kaitannya dengan upaya pengembangan wawasan pengetahuan dan keterampilan pengolahan limbah plastik menjadi produk kreatif, maka program pengabdian masyarakat ini dilakukan dalam bentuk transfer iptek yang dilakukan berupa sosialisasi, pelatihan, dan pendampingan kepada Ibu PKK desa Kuala Langsa yang akan mengolah limbah bungkus kopi menjadi kerajinan tangan yang berbentuk tas, han bag serta produk kreatif lainnya yang mampu bersaing secara lokal dan nasional.

Ibu PKK yang dilatihkan dapat diproduktifkan kinerjanya dalam usaha produksi rumahan yang sifatnya sambilan dengan mengolah sampah bungkus kopi yang sifatnya inovatif untuk membuka lapangan pekerjaan baru dalam menunjang pemasukan kebutuhan seharihari. Dipilihnya sasaran Ibu PKK, selain merupakan kelompok masyarakat yang rutinitasnya identik dengan keterlibatannya dalam proses pengembangan dan pemberdayaan kaum perempuan desa, juga merupakan masyarakat yang memiliki tingkat produktivitas mobilisasi yang tinggi dalam penyebar luasan informasi, terutama yang berkaitan dengan wawasan pengetahuan dan keterampilan yang Ibu PKK peroleh pada saat penyelenggaraan program Pengabdian pada Masyarakat Universitas Samudra.

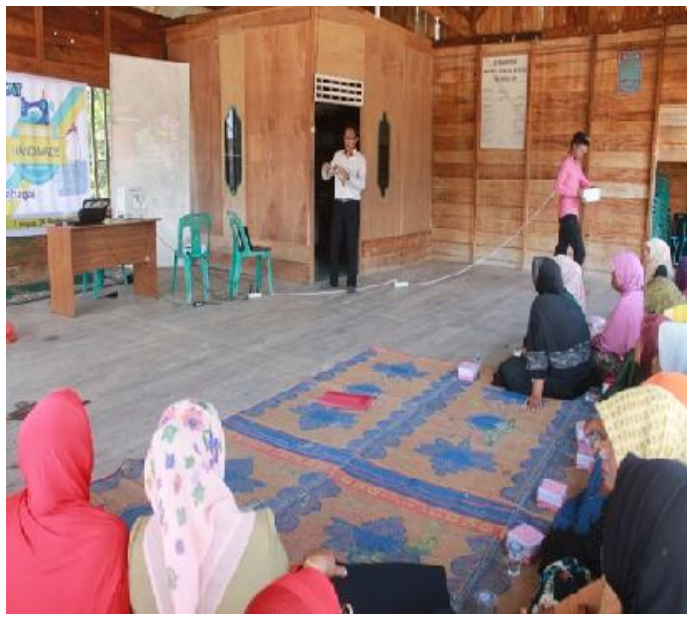

Gambar 3: Penyampaian Materi

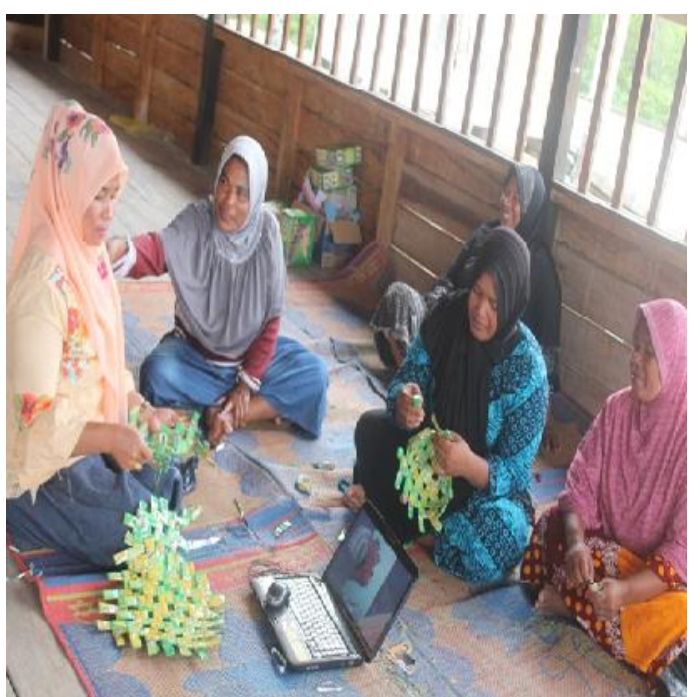

Gambar 4: Pembuatan Tas Handmade 


\section{Tahapan Evaluasi Kegiatan}

Adapun alur pelaksanaan program pengabdian ini dimulai dari, (1) Tahap persiapan, yang terdiri dari tahap: (a) penyiapan bahan administrasi sesuai dengan kebutuhan pelaksanaan sosialisasi, (b) melakukan koordinasi dengan Geuchik Kuala Langsa (c) menyiapkan materi pelatihan, (d) menyiapkan narasumber yang memiliki kompetensi sesuai dengan target dan tujuan pelatihan, dan (e) menyiapkan jadwal sosialisasi menyesuaikan dengan perencanaan kegiatan yang telah terprogram, (2) tahap pelaksanaan, yang terdiri dari: (a) melakukan sosialisasi pelatihan pengolahan bahan baku (b) diskusi terbatas mengenai pemahaman wawasan dan keterampilan yang sudah mampu peserta kuasai, dan (3) tahap evaluasi, yang terdiri dari (a) persentasi kesimpulan sosialiasi oleh tim pelaksana dan praktek pelatihan langsung bagi peserta, (b) refleksi berupa praktek dari pakar dengan uji coba program yang sudah dilatihkan, dan (c) memberikan penilaian terhadap produk yang dihasilkan oleh peserta program pengabdian.

Untuk mengukur tingkat
keberhasilan kegiatan yang telah dilakukan, maka akan dilakukan evaluasi minimal 3 (tiga) kali, yaitu evaluasi proses, evaluasi akhir, dan evaluasi tindak lanjut. Kriteria dan indikator pencapaian tujuan dan tolak ukur yang digunakan untuk menjastifikasi tingkat keberhasilan kegiatan

Setelah diberikan pelatihan oleh tim pelaksana dari Universitas Samudra, Ibu PKK di Desa Kuala Langsa dapat memahami dengan jelas materi sosialisasi dan pelatihan mengenai penglohan limbah bungkus kopi menjadi produk yang kreatif. Para peserta sangat antusias dalam melakukan kegiatan pengabdian dikarenakan menambah pengetahuan dan hasil produk yang mereka buat nantinya dapat dipasarkan khususnya di Kota Langsa.
Hal ini dapat dilihat dari hasil diskusi dan evaluasi yang dilakukan oleh tim pelaksana pengabdian pada masyarakat Universitas Samudra, terhadap pengetahuan dan keterampilan peserta sosialisasi dan pelatihan. Berdasarkan evaluasi tindak lanjut yang dilakukan, ditemukan bahwa Ibu-ibu di Desa Kuala Langsa yang mengikuti pelaksanaan program memiliki pengetahuan yang konsisten mengenai keterampilan pengolahan limbah bungkus kopi.

Berdasarkan hasil evaluasi tidak lanjut juga terekam, beberapa manfaat praktis yang diperoleh oleh Ibu-ibu di Desa Kuala Langsa, yaitu:

(1) Mereka mendapatkan informasi yang jelas dan utuh mengenai hakekat pemberdayaan masyarakat dari segi pengetahuan dan keterampilan, bermakna untuk penciptaan lapangan pekerjaan baru yang sifatnya inovatif dari pengembangan industri rumah tanggga dari Ibu-ibu

(2) Ibu-ibu yang menjadi peserta pelatihan memperoleh gambaran yang jelas mengenai langkah pengembangan iklim usaha dengan memanfaatkan limbah bungkus kopi

(3) Peserta pelatihan juga mendapatkan gambaran yang jelas dan utuh tentang manfaat limbah jika dikelola dengan baik.

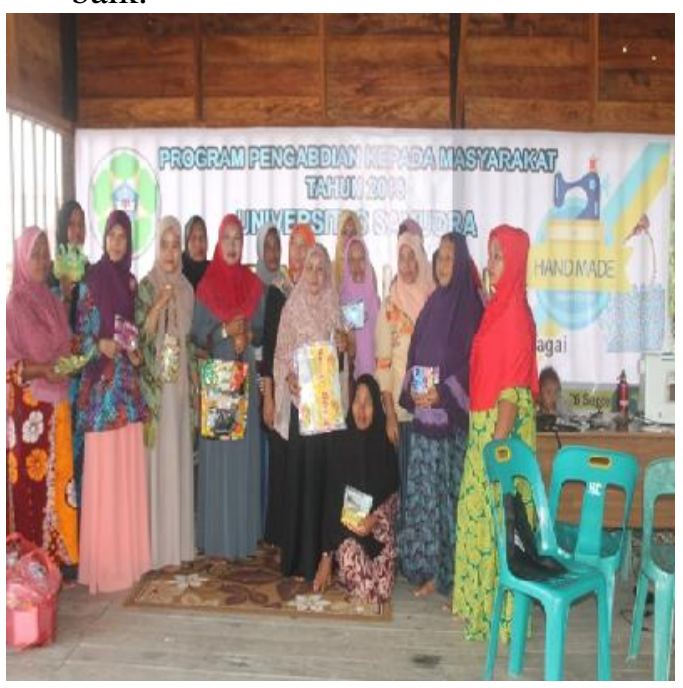

Gambar 5: Foto Bersama Ibu-Ibu Desa Kuala Langsa 


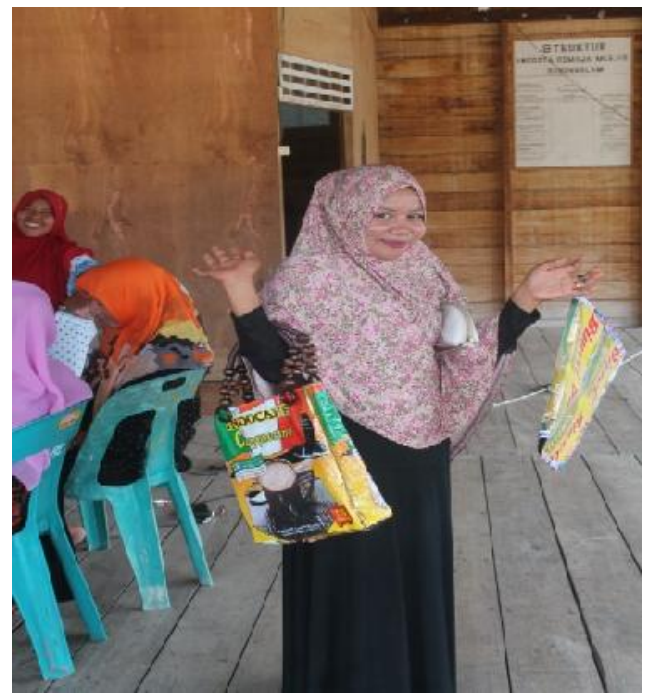

Gambar 6: Hasil Produk Kegiatan

\section{SIMPULAN}

Simpulan yang dapat diperoleh dari pelaksanaan program pengabdian kepada masyarakat "Pengolahan Limbah Plastik Menjadi Produk Kreatif Sebagai Peningkatan Ekonomi Masyarakat Pesisir" adalah: (1) Tingkat partisipasi yang tinggi dari mitra program pengabdian kepada masyarakat memberikan dampak positif bagi pelaksanaan program, terlihat dari pelatihan dan pendampingan dalam pembuatan produk, (2) Pelaksanaan program mampu menghasilkan produkproduk yang memiliki nilai jual yang tinggi khususnya di Kota Langsa sehingga mampu meningkatkan perekonomian masyarakat pesisir.

\section{UCAPAN TERIMA KASIH}

Terima kasih kepada Universitas Samudra yang telah memberikan Dana Pengabdian Kepada Masyarakat tahun anggaran 2016.

\section{DAFTAR PUSTAKA}

Badan Pusat Statistik. 2015. Langsa Dalam Angka2015.

Dharmawansyah. 2015. Optimasi Teknis Operasional Persampahan Kota Studi Kasus Gampong Jawa Kota Langsa. Tesis. Universitas Sumataera Utara.

Putra, H. P dan Yebi, Y. 2010. Studi Pemanfaatan Sampah Plastik Menjadi Produk dan Jasa Kreatif. Jurnal Sains dan Teknologi Lingkungan. Vol. 2 No. 1.

Surono, U. B. 2011. Berbagai Metode Konversi Sampah Plastik Menjadi Bahan Bakar Minyak. Jurnal Teknik. Vol. 3 No. 